UDC 821.161.2-1.09

DOI https://doi.org/10.32841/2409-1154.2020.45-1.12

\author{
Naumenko N. V., \\ Doctor of Philology, Professor, \\ Professor at the Department of Foreign Languages for Specific Purposes \\ National University of Food Technologies
}

\title{
ONOMATOPOEIAS OF CONTEMPORARY UKRAINIAN POETRY IN THE ASPECT OF ARTISTIC SYNTHESIS
}

Summary. The associative conceits, evoked by a concrete image in an author, a reader, or a speaker of a free-verse lyrical work, often get divergent, bearing a resemblance to the complicated system of concentric circles. However, they would converge on the certain level of perception, owing to the fact that the coincidences of associative fields are able to reveal the archetypal content of initial images.

Establishment and development of the problematic circle in Ukrainian free verses of the $20^{\text {th }}$-the beginning of the $21^{\text {st }}$ century can be described by combinations of urban and rural elements, setting up and solving the existential binary oppositions, reflections over the national renaissance of the homeland, and personification of nature. This was what has conditioned the openness of free verse form to artistic synthesis. There is impossible not to notice the echo of impressionistic arts in the up-to-date interpretations of landscape lyrics in freeverse works of the period analyzed (written by M. Semenko, V. Polischuk, R. Kudlyk, and I. Andrusiak). Particularly, it is expedient to talk about the combination of painting (showing an object under various angles and lighting), poetry (operating with a large array of tropes and figures to fix the impression and to suggest it to a reader), and music.

Therefore, the artistic imagery of a poetic work synthesizes the visual and audible component in its intonation dimension. This will significantly enlarge the volume of esthetic information, together with the speaker's emotional attitude which is able to suggest an image expressed in a poem to a reader. To reach the proper acoustic effect, poets use the ideophones (or onomatopoeias) and puns connected with them to create either overt or latent metaphors, constructing the image of a sounding thing or entity. Sometimes onomatopoeias get substantiated in poetry, taking even the role of subjects or predicates. This can not only create the audible artistic conceit, but also give it a sense-making function. This way the poet can concentrate any audible element to 'a point within an idiom,' activating the imagination and artistic thinking of a poem's addressee.

Key words: Ukrainian poetry, lyrics, free verse, onomatopoeia, image, nature, synthesis.

Setting up the problem. Ideophones (another term for onomatopoeias) used in a poetic work help an author or a recipient to set up the image of any sounding thing or entity [3, c. 121]. According to Ivan Franko, the sense of hearing allows cognizing the wide arrays of some transient, imperceptible, volatile phenomena, and the wide arrays of defiant and strong shifts that strike human souls [9, c. 80]. Although the onomatopoeias (and interjections as a whole) are not the valuable parts of a sentence, they sometimes get substantiated in poetry, taking even the role of subjects or predicates. This can 'not only create the audible artistic conceit, but also give it a sensemaking function' [10, p. 99]. Such a means is frequently used in free verse language, compressing the whole world reflected in it to 'a point in a syntagm' and therefore activating the attention of a lyrical poem addressee.

Analysis of the up-to-date researches and publications. The onomatopoeias as the means of lyrical image-making are still remaining under discussion of linguists as well as of literary critics (Yevhen Adelheim, Ihor Kahcurovsky, Nataliia Kostenko, Anatoliy Tkachenko et al.). The main conclusion is this: from the very beginning of the 20th century, Ukrainian poets, particularly the free verse writers, took the onomatopoeias and subsequently posed them as the sophisticated imagery complexes. The latter have got the subsequent definitions in scientific works: phonic mimesis, the simple reproduction of the sounds of nature (twit-twit, jug-jug, bow-wow, meow, cuckoo, chirr, bang, slap, ding, dong, hiss, hush, ticktock etc.): onomatophony, the more complex stage of combination and using the words which are onomatopoetic in shape but independent in sense - nouns, adjectives, verbs and so on (to meow, to cuckoo, to chirr, to tick, a chirrup, a slap, a bang etc.); phonopoeia (Greek phonos - the sound and poeia - the made, something made of the sound), the achievement of the proper acoustic effect in varying and combining the words which are not onomatopoetic but suggest the illusion of sounding by special phonemic background alliteration, assonance etc. [See 3, c. 121; 8, c. 312; 11, p. 54].

Formulation of the purpose of the article. This work is aimed to confirm the onomatopoeias the factors of renewal of the elements of ancient Slavic pantheistic worldview in contemporary Ukrainian poetry, including free verse as the sample of spontaneous poetic speech.

Results and discussions. The early $20^{\text {th }}$ century poets futurists and impressionists - were the first to widen the functions of onomatopoeias to the level of a self-dependent word. Consequently, the phonic mimesis as the initial dimension of phonic imagery became the main artistic factor to show the sounds and movements of an environment and to project them on the author's internal reflections and impressions. This was the way for the writers to create the images of both the urban and the rural space, which were 'crucially important for the literary process in Ukraine' [10, p. 100] up to now.

The urban landscape, which was conceptual for Ukrainian futurist poets, can be represented in the works by Mykhail' Semenko:

Pfff / puffin' and sniffin' / ssssh / noisily hissing behind the machine..

cough cough cough

! and You ["The Poem." 7, c. 149; all the quotations from poems are hereinafter translated by the author of this paper].

The rural images are prevalent in free verses by Semenko's contemporary, Valerian Polischuk, the poet usually related to constructivists: 
3 квадрових рамчаків / Спімать бджілки одна по одній:

Бзум, бзум - /Вдаряе кожна, вилітаючи з очка,

У котрунебуть з невидимих струн,

Що перетягнені од неба до землі, мов на ичимбалах -

Не оминеш ніяк, щоб не ударить...

Out of the square frames / The bees are hurrying one by one:

Zoom, zoom - / Flying out of a hive, a bee is hitting

A certain invisible string

That's pulled from earth to heaven, like a dulcimer-

There is no way to pass it without hitting ["The Apiary." 6, c. 143].

Starting from phonic mimesis as the initial image-making force, the poets had reached the most complicated syntactic level of interaction between onomatopoeias and non-onomatopoeias, which can be called 'phonopoeia'. For example, in M. Semenko's poems it looks like this:

Осінь і осінь

I ще раз осінь

І жовте листя змітає в сквері сторож

... а враниі туман

ніби сірі гуси вкрили місто

$к р а к р а$

осінь стара карга

autumn and autumn

and autumn once more

and a watchman is sweeping the fallen leaves out...

and fogy's the morning

as if the gray geese have covered the city

crow crow crow

autumn's a real old crone ["Autumn." 7, c. 272-273].

Imitation of crows' voices (crow crow crow) helps the poet create the semantic field that includes the sonic conceits 'morning,' 'gray,' 'covered,' 'real crone' and gets closed in an ironically intoned last line, 'dayte pozhalusta prykuryt" ('Light me a cigarette please.')

The onomatopoeias from the animal world occupy the very significant place in Ukrainian poetry up to nowadays. Showing the natural environment in mobile sensory images, the characters of any literary work try not only to reproduce the sound of a favorite entity (purling of a stream, chirping of birds, buzzing of insects, barking of dogs, meowing of cats etc.), but also join themselves symbolically to the life of nature.

Valerian Polischuk took the onomatopoeias from nature as the key compositional means of image-making in his late free-verse works. Besides The Apiary cited before, there is one more brilliant poem, The Crickets:

Як повен яр - мелодія звучить: / То пробують на флейту ивіркуни

Рапсодію веселу - / Тюр-р... тюр-р...

Full is the plain - the melody's resounding:

These are the crickets trying to play

A jolly rhapsody on flute: / Chirr... chirr... [6, c. 53].

The sonic images are here functioning in creation of a semantic field 'human - nature':

Цюркочуть, / Немов иңюрком біжить демолоко в дійнищю...

І сниться, / Що то передосінній гул

(В полях гуляе серпень)...

Chirring all night away, / As if the stream of milk is running to a pail...
I'm dreaming / There was a before-autumn humming

(August is walking thro the fields).

The essential function of the sonic image presented in the poem is to involve the other sensory conceits into the symbolic trinity 'human - nature - civilization':

Цвіркун... співа собі, сигналізуючи, як іскра радіо,

що вже дзижчить там у світи...

А він (цвіркун) телеграфує:

Тюр-р... // Тюр-р... // Тюр... тюр... // Тюр-р... / І так далі.

A cricket... keeps on singing,

Signaling just like sparks of radio

Pouring its buzz into the air...

And lo, a cricket is telegraphing:

Chirr... chirr... chir-chir... chirr... / Et cetera [6, c. 54].

Another example (a quotation from Polischuk's The Early Spring) gives the synthesis of phonic mimesis and phonopoeia, which could be reproduced like this in translation:

Півні в повітрі п'янім / Ясні голоси

Простягують криштальними полями.

Не пропаде нігде ні шерх, ні стук...

тутука дятел в сук.

The roosters in the drunken air / Are spreading their clear voices Above the crystal plains...

Neither the rustle nor the knock is lost somehow...

A woodpecker's tock-tocking at a bough [6, c. 55].

In Polischuk's work with an eloquent musical title, The Forest Singing (which can be interpreted as an allusion to Lesya Ukrayinka's The Forest Song), the voices of nature embodied in words make a contrast with the sounds of personified machines. This appears to be a symbol of the constant diffusion between the worlds of nature and human:

тріщать сухі шишки під босими ногами...

Знайомий горлинки мотив,

Що десь клопочеться, вкладаючи дітей непосидющих на ніч,

Лоскоче горло...

Зарокотав до бору, ще й свиснув на коня

Козак-локомотив...

Dry cones are cracking under bare feet...

Lo, a familiar tune of a turtle-dove,

Who fusses somewhere, making her fledglings go to bed,

Tickles her throat...

And over there, the Cossack-locomotive

Roared to the woods, and whistled 'saddle-up'... [6, c. 57].

Euphonic sequences of sounds that evoked the speaker's wish, 'if the sky was gilt / by this clear day / to see the Nature well' («щоб небо золотив / Ще ясен день, / Щоб бачити природу»), have reached their iconic embodiment in a formally and substantially symbolistic 'voice of heart':

«Нащо тобі думок така плетінь, / Коли ие тінь,

Все тільки тінь, / Як шелести вільхові

I дух осикових солодких лопотінь»... a shade

'Why do you need to join the senses in a braid / While it's

Only a shade, / Just like the alders rustling

And aspens sweetly smelling on a glade' [6, c. 58]. 
This synthesis of pure onomatopoeias and sonic game with selfdependent words is reflected in the entire poetic cycle, The Nature, which is a part of Polischuk's poetic collection with a profoundly symbolic title, Radio $v$ zhytakh (Radio in Rye Fields).

Birds were considered by the writers the live symbols to express the flight of time, the connections between human and nature. An image of a bird is closely tied to the element of Air, and therefore the birdsong, transcribed in the poetic narration by sounds of human speech, gets identified to the natural meta-language.

Forcomparison: the representatives of Russian 'Silver Age' wrote the highly-artistic works based on the sequences of onomatopoeias. One of them is the below cited excerpt from Zia-zing, a poem from Vasyliy Kamenski's book Zvuchal'vesneyanki, which is quite an interesting field for experiments in poetic translations. It is also to note that 'the name of the entire poetic collection is supposed to be created of two contaminated Russian words: first, 'zvuchat,' to sound, plus 'pechal', sadness; and second, 'vesna,' the spring, plus '-yanka,' a Slavic female suffix for the names of nationalities, professions, and statuses' [10, p. 101]. Therefore, we can interpret this title as Soundess of a Springwoman:

\section{Циа-цини-цвилью-ций}

Цвилью-ций-ций-тюрль-ю -

День-деньской по березнику звонкому

Как у Божиих райских дверей

Или как у источника радостей

Слышны пташек лесных голоса...

Zia-zing-zwillio-zie

Zwillio-zie-zie-turr-liu -

Day by day in the green ringing birches

Like near God's Gates to Paradise

Or like next to the source of joys

Hear the re-sounding voices of birdies [2, c. 80].

From thence, the traditions of onomatopoeic writing initiated by futurists and impressionists in 1920s-1930s have been creatively interpreted in Ukrainian 'shistdesyatnyks' (the poets who made their debuts in the 1960s) lyrics. The method to use the birds' voices with good effect can be epitomized by Roman Kudlyk's poem 'Tvorchy Den' (An Inspired Day) that has got the ironic intonation in V. Polischuk's manner:

Лірик Дощовий Хробак / Своїм письмом піктографічним

Натхненно творив сонет...

“Ко-ко-копіювання! Плагіат!” - / обурився критик Kогут...

Earthworm the Lyric / Was inspiredly jotting down a sonnet

By pictographic characters on sand.

"It's co-co-copying! It's plagiary!"

Rooster the Critic clucked with disguise...[4, c. 26].

There would be no exaggeration to say that Roman Kudlyk has intentionally used the dialectal West Ukrainian word 'kogut' (a rooster) instead of a literary 'piven,' to make an internal rhyme with an onomatopoeia 'co-co.' The latter, having been immediately transformed into a valuable word, appears to be 'a conceptual means to stenograph the 'replicas' uttered by other birds' [5, c. 295]:

Горобещь-поліглот... перекладав на ассирійську мову

«Баладу про дезоксирибонуклеїнову кислоту».

«Ге-ге-ге-ніально, - зателтотали Гуси...

Краще, ніж в оригі-гі-гі-налі».
A Sparrow polyglot... was translating the Ballad of Deoxyribonucleic Acid' into Assyrian language.

'Gla-glamorously genial,' cackled the Geese,

'Far glo-glo-glossier than in an original.'

A hyperbolized 'death of arts,' embodied in the figure of the narrator's wife, gets onomatopoeic as well:

Max-мах (мітлою.-Н.Н.)-/По піктографії, /По клинопису,

По монументу скляному...

«Ге-ге-ге-рострат у спіднииі, - / зойкнули Гуси, -

Ги-ги-ги-не мистеитво!»

A wave, a wave (with a broom. - N.N.) -

On the pictography, / On cuneiforms, / On glassy monument...

'Ge-Gerostrates skirted,' yelled the Geese,

'Go-go-go-gone's the Art!' [4, c. 27].

In Kudlyk's verse, the contradiction between 'the poetic' and 'the quotidian,' well-known from Romanticism, is solved in the favor of the latter - as the woman said, «Може, кинеш свою писанину? / Приніс би ліпше води!» ('Well, put your scribbles aside, / You'd better go and bring some water!'). This is the fact that makes a speaker utter with desperation, «Справдi, / гине мистеитво!» (The art is really gone!).

Furthermore, the represented way of image-making has been actualized in poetry by Ivan Andrusyak, our contemporary. However, this poet managed to create a strong counter-point (Wendepunkt) out of the onomatopoeias only, which observation allowed us to define the following verse work, Impossibilities of Language, the 'verse novella' $[10$, p. 101-102] and therefore to recite it wholly:

jug jug jug jug / twit twit / twittio

and again: / tit tit tit tit tit / chirrup

and buzzzzzzzzz - a bug

and so on: / twit twit twit / twittio

eh I wish I saw just one of them / but no - I see only a bug

yet the bug's the one I do not want to talk to

cause my oh my / what would I say to the bug?

Just think a little... [1, c. 7$]$

Conclusions. The analysis of verse works with onomatopoeias for the main factors of image-making allowed us to conclude that the greatest attention was paid to them, first of all, by the early 20th century poets - futurists, impressionists and constructivists. It is quite evident that impressionists, trying to catch the moment, were concentrated on visual and sonic images in motion; moreover, futurists and constructivists as almost similar poets in style gave the onomatopoeias the prominent role in their works (sometimes composing the whole syntactic periods or stanzas of them). The onomatopoeia reveals the experimental nature of a separate poem, so that it confirms the continuity of language development, particularly in the field of expressing the nature in sensory images.

The further synthetic studies of semantics of onomatopoeias in Ukrainian poetry (the shistdesyatnyks, or the poets of the 1960s, and post-modern writers) will allow observing that the deeper an author gets into the internal form of a word (first of all, dissociating it, or creating the acoustic effect by sequences of the similar sounds, or combining an onomatopoeia with a self-dependent word), the wider becomes the range of the meanings of a certain cultural conceit. 
Therefore, the phonic themes completing each other throughout a poem are finally integrating into a full-sounding symbolic picture that is reflecting the large array of human spiritual activity and the versatility of the entire human life.

\section{References:}

1. Андрусяк I. Неможливості мови: поезії та переклади. Київ : Ярославів Вал, 2011. 151 с

2. Каменский В.В. Звучаль веснеянки: [стихотворения]. Москва : Китоврас, 1918. 160 с.

3. ачуровський I. Фоніка : підр. для студ. філол. факультетів вузів. Київ : Либідь, 1994. 168 с.

4. Кудлик Р.М. Весняний більярд: вірші. Київ : Молодь, 1968. 68 с.

5. Науменко Н.В. Серпантинні дороги поезії: природа та тенденції розвитку українського верлібру : монографія. Київ : Видавництво «Сталь», 2010. 518 с.

6. Поліщук В.Л. Вибране / вст. ст., упоряд., примітки 3. Суходуба. Київ : Дніпро, 1987. 317 с.

7. Семенко М. Поезії / вст. ст., упоряд., прим. Є. Адельгейма. Київ : Рад. письменник, 1985. $311 \mathrm{c}$

8. Ткаченко А.О. Мистецтво слова: Вступ до літературознавства: підручник для студентів гуманітарних спеціальних вищих закладів. Київ : ВПЦ «Київський університет», 2003. 448 с.

9. Франко І.Я. Із секретів поетичної творчості. Зібрання творів: у 50-ти т. Т. 31: Літературно-критичні праці. Київ : Наукова думка, 1980. С. 45-119.

10. Naumenko, N. The Esthetic Possibilities of Onomatopoeias in Contemporary Ukrainian Poetry. Advanced Science. Volume 2015. Issue 1. P. 99-102.

11. Perrine, L. Arp, T. Sound and Sense: An Introduction to Poetry. New York : Harcourt Brace College Publishers, 1992. 401 p.

Науменко Н. В. Звуконаслідування сучасної української поезії в аспекті синтезу мистецтв

Анотація. Асоціації, як образ, виражений конкретним поняттям, викликає в автора, реципієнта й ліричних персонажів верлібрової поезії різні почуття, являючи собою складну систему концентричних кіл. Але на певному рівні сприйняття вони збігаються. Адже на стику асоціативних полів, творених довкола образу, вельми часто приховується первозданне - архетипне його значення.

Становлення та розширення проблематики українських верлібрів XX - початку XXI століття - поєднання урбаністичних i рустикальних елементів, постановка та розв'язок екзистенційних бінарних опозицій, рефлексії на тему національного відродження країни, одухотворення природи - визначило відкритість вільної форми до взаємодії мистецтв. У вільних віршах даного періоду (автори - М. Семенко, В. Поліщук, Р. Кудлик, І. Андрусяк), неможливо не помітити відголосок імпресіоністичного мистецтва - живопису, однією з рис якого $є$ змалювання об'єкта природи під різними кутами зору й у різному освітленні; поезії, яка у спробі зафіксувати враження та передати його реципієнтові, оперує великим діапазоном зображально-виражальних словесних засобів (від фігур недомовленості до верлібрового темпоритму), та музики.

Отже, художня мова вірша має сприйматися як візуально, так і на слух, в інтонаційному звучанні. Це значно посилює обсяг естетичної інформації, додаючи до неї емоційне ставлення мовця та сугестуючи його читачеві. Задля досягнення акустичного ефекту поети звертаються до ономатопей та пов'язаних із ними каламбурних слів, творячи прямі або приховані метафори, за допомогою яких у реципієнта створюється образ певної речі або істоти, яка звучить. Іноді звуконаслідування субстантивуються, виступаючи в ролі підмета або присудка, завдяки чому підноситься їхня естетична роль - не лише створення звукового образу, а й надання йому смислоутворювальної функції. Таким прийомом поет здатен сконцентрувати світ до «точки в синтагмі», тим самим активізуючи увагу та художнє мислення адресата ліричного твору.

Ключові слова: українська поезія, лірика, верлібр, ономатопея, образ, природа, синтез. 